\title{
The Effect of Brand Image Perception and Product Quality Toward the Interest to Buy Consumer Pre-Pay IM3 Ooredoo
}

\author{
Didin Fatihudin $^{1 *}$, Mochamad Mochklas ${ }^{1}$, Dika Arista Suryati ${ }^{1}$ \\ ${ }^{1}$ Faculty of Economics and Business, University of Muhammadiyah Surabaya, Surabaya, Indonesia \\ *Corresponding author. Email: dienafdloka@gmail.com
}

\begin{abstract}
Indosat Ooredoo is a telecommunications network service provider company in Indonesia. The company offers communication channels for prepaid and post-paid telephone users under the brand names Matrix Ooredoo, Mentari Ooredoo and IM3 Ooredoo. IM3 Ooredoo is able to capture a wide market share, especially among adolescents, students and students. IM3 Ooredoo also provides multimedia, internet and MIDI data communication services (Multimedia, Internet \& Data Communication services). The method of this research approach with quantitative methods, the technique of collecting data was questionnaire with accidental sampling technique which was 60 respondents. The analytical method uses multiple linear regression analysis through normality test, hypothesis test, $\mathrm{F}$ test, and $\mathrm{t}$ test. The data collected was processed using SPSS which produces a regression equation $\mathrm{Y}=2,422+0,421 \mathrm{X} 1+0,289 \mathrm{X} 2+\mathrm{e}$. From the results of the $\mathrm{F}$ test showed that the variable brand image and product quality simultaneously affect the consumer purchase interest while the $t$ test shows that product quality is a variable that has a dominant influence on consumer purchasing decisions.
\end{abstract}

Keywords: brand image, product quality, consumer purchasing decisions

\section{INTRODUCTION}

Indosat Ooredoo or PT. Indosat Tbk is a telecommunications network and service provider company in Indonesia [1]. The company offers communication channels for telephone users with prepaid and postpaid options under the brand names Matrix Ooredoo, Mentari Ooredoo and IM3 Ooredoo. IM3 Ooredoo is able to capture a wide market share, especially among teenagers, students and students who prefer to use $4 \mathrm{G}$ network services [2]. 4G is stable and wide and has a large internet capacity with a fast internet connection. IM3 Ooredoo also provides multimedia, internet and MIDI data communication services (Multimedia, Internet \& Data Communication Services).

Perception is the process of how the stimuli are selected, organized, and interpreted [3]. Perception is a process that arises due to sensation, where sensation is the activity of feeling or causing an exhilarating emotional state. Sensation can also be defined as a quick response from our recipient's senses to basic stimuli such as light, color, and sound. With all this, perception will arise [4].

Purchasing interest is a model of a person's attitude towards objects of goods which is very suitable in measuring attitudes toward a certain class of products, services or brands. Buying interest is considered as a measure of the likelihood of consumers buying a particular product, where the high buying interest will have a significant impact on the purchase decision [5]. Buying interest is the tendency of consumers to buy a brand or take action to relate to a purchase that is measured by the likelihood of consumers making a purchase. From this understanding, it can be concluded that consumer buying interest is the attitude of someone who will buy a product or use a service in the presence of measurement or assessment of their brand [6]. One factor that is taken into consideration in the purchase of a product is the brand image [7]. Brand Image relates to attitudes in the form of beliefs and preferences towards a brand. What consumers think and feel when hearing or seeing a brand. Brand image is the perception and belief held by consumers [8], as reflected by the association embedded in the customer's memory, which is always remembered for the first time when hearing slogans and embedded in consumers' minds [9]. Product quality is a characteristic of a product or service that depends on its ability to satisfy customer needs that are stated or implied [10]. Product quality is an important benchmark for the success of a company. With good product quality, the company will be able to compete with its competitors. There are 3 indicators of brand image namely: corporate image, user image, and product image. consumers, and guarantees [11].

Quality products and a good brand image (key brand image) is the main key in winning the competition, in the end it will be able to provide a higher value of satisfaction to consumers. Consumers now have demands of a much greater value and variety because they are faced with various choices of products (services) that can be purchased [12]. Smart companies will try to fully understand consumer decision-making processes, all their experiences in learning, choosing, and even using products. Among the alternative processes and decision making there is consumer buying interest [13]. So it can be concluded that the brand 
image is an intermediary influence of product quality on consumer purchasing decisions [14].

The main value expected by customers from producers is the highest quality of products and services. Consumers always hope that the goods they buy can satisfy their wants and needs. For that, companies must be able to understand the desires of consumers so that the products produced are in line with consumer expectations. characteristics of an item or service that affect its ability to satisfy expressed or implied needs [15]. Product quality is something that needs to get the main attention of the company or manufacturer, considering the quality of a product is closely related to customer satisfaction, which is the goal of marketing activities undertaken by the company [16].

Some of the prepaid simcard brand performance from 20132017 are well known by Indonesian consumers. IM3 Ooredoo's prepaid simcard brand performance has decreased significantly from $201615.4 \%$ to $13.6 \%$ in 2017 [17]. Based on the background and problems above, companies must improve their brand image (brand image) and always provide the best quality products so that in the future it can have an impact on increasing consumer buying interest for IM3 Ooredoo prepaid simcards. In this case, the researcher is interested in conducting a study of Brand Image perceptions and Product Quality Towards the IM3 Ooredoo prepaid consumer purchase decision ". The purpose of this study is to test and analyze the influence between the perception of brand image and product quality on the purchasing decision of IM3 Ooredoo prepaid consumer card. To partially test and analyze which dominant influence between brand image perception and product quality on IM3 Ooredoo prepaid consumer card purchasing decisions.

In every business only, marketing and innovation creates value while others create costs. Marketing is a social and managerial process where individuals and groups get their needs and desires by creating, offering and exchanging products that are of value to each other [18]. Marketing is one of the activities in the economy that helps in creating value [19]. Based on these explanations, marketing is an activity that is most important for companies to increase sales of products or services by creating various innovations and having value.

The notion of image is the way people perceive and evaluate the brand actually. In order for an image to be embedded in the minds of consumers, marketers must show brand identity through brand communication and contact advice available [10]. Brand image is a public perception of the company and its products. An effective image will affect three things, namely: (1) strengthening the character of the product and the proposed value, (2) conveying the character in a different way so as not to be confused with the competitor's character, (3) providing emotional strength that is more than a mental image. Brand image is also a description of associations and consumer confidence in certain brands. Brand image is the observation and trust held by consumers, as reflected in consumers' associations or memories.

\section{RESEARCH METHODS}

This research method is ex post facto. Quantitative approach uses Multiple Linear Regression, SPSS program version 25 . Primary data is done by collecting the researcher directly from the research object. Secondary data is a source that does not directly provide data to data collectors. The independent variable in this study is Brand Image and Product Quality. dependent variable Consumer purchasing decisions. Total 60 respondents. Using non-probability sampling with convenience sampling or also called accidental sampling.

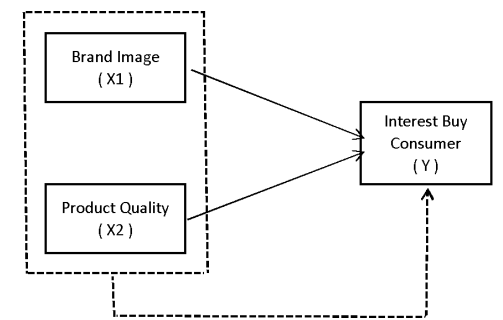

Figure 1 Conceptual Framework

Hypothetically; Simultaneously suspected to exist; significant influence between brand image (X1) and product quality (X2) on consumer purchasing decisions (Y) of IM3 Ooredoo prepaid simcard. Partially, it is suspected that the dominant product quality (X2) influence on consumer purchasing decisions (Y) is IM3 Ooredoo prepaid simcard.

\section{RESULTS AND DISCUSSION}

Respondents in this study were Indosat prepaid card buyers in Surabaya. Researchers distributed 250 questionnaires, but only 244 questionnaires could be used as research data. The response rate of $96.6 \%$ due to 6 questionnaires did not return, so it cannot be used as research data.

From the table of validity test results, in each item the value of $R_{\text {count }}>R_{\text {table }}(0.254)$ so that the data obtained from the study indicate that each item statement on each variable can be declared valid. Reliability Test; Cronbach value of alpha variable Brand Image (0.267) and Product Quality (0.674), Consumer Purchase Interest (0.595) is greater than 0.70 so that it can be said that the data is reliable.

Table 1 F Test Result

\begin{tabular}{|c|c|c|c|c|c|c|}
\hline \multicolumn{2}{|c|}{ Model } & $\begin{array}{l}\text { Sum of } \\
\text { Square }\end{array}$ & Df & $\begin{array}{l}\text { Mean } \\
\text { Square }\end{array}$ & $\mathrm{F}$ & Sig. \\
\hline \multirow[t]{3}{*}{1} & Regression & 78.757 & 2 & 39.378 & \multirow[t]{3}{*}{39.086} & \multirow[t]{3}{*}{$.000^{\mathrm{b}}$} \\
\hline & Residual & 57.427 & 57 & 1.007 & & \\
\hline & Total & 136.183 & 59 & & & \\
\hline $\mathrm{a}$ & $\begin{array}{l}\text { Dependent } \\
\text { Predictors: }\end{array}$ & $\begin{array}{l}\text { able: Interes } \\
\text { stant), Prod }\end{array}$ & $\begin{array}{l}\text { 3uy Co } \\
\text { t Qual }\end{array}$ & $\begin{array}{l}\text { umer } \\
\text { Brand }\end{array}$ & & \\
\hline
\end{tabular}

Source: Processed Data researcher (2019)

Table 1 shows the $\mathrm{F}_{\text {test }}$ results above, it appears that the $\mathrm{F}_{\text {count }}$ is 39.086 with a significance of 0.000 . While the size of $F_{\text {table }}$ is 2.54. Thus, $\mathrm{F}_{\text {count }}(39.086)>\mathrm{F}_{\text {table }}(2.54), \mathrm{F}_{\text {count }}$ is greater than $\mathrm{F}_{\text {table. }}$. Based on the $\mathrm{F}_{\text {test }}$ test criteria, then $\mathrm{H}_{1}$ is accepted and $\mathrm{H}_{0}$ is rejected or in other words that the allegation that 
states Brand Imaged and product quality has a significant effect on the purchasing decision of IM3 Ooredoo prepaid simcard consumers.

Table 2 t test result

\begin{tabular}{|c|c|c|c|c|c|c|}
\hline & \multirow{2}{*}{ Model } & \multicolumn{2}{|c|}{$\begin{array}{c}\text { Unstandardized } \\
\text { Coefficients } \\
\end{array}$} & \multirow{2}{*}{$\begin{array}{c}\text { Standardized } \\
\text { Coefficients } \\
\text { Beta }\end{array}$} & \multirow{2}{*}{$\mathrm{t}$} & \multirow{2}{*}{ Sig. } \\
\hline & & B & $\begin{array}{l}\text { Std. } \\
\text { Error }\end{array}$ & & & \\
\hline \multirow[t]{3}{*}{1} & (Constant) & 2.422 & 1.706 & & 1.419 & .134 \\
\hline & Brand Image & .421 & .134 & .317 & 3.147 & .003 \\
\hline & Product Quality & -.013 & .053 & .546 & 5.419 & .000 \\
\hline a & Dependent Vari & :Cons & er Purc & Interest & & \\
\hline
\end{tabular}

In this study partial testing $\left(t_{\text {test }}\right)$ is used to determine whether the independent variable Brand Image (X1) and Product Quality (X2), on Consumer Purchase Interest (Y). Based on the $t_{\text {test }}$ can be obtained on the product variable shows the value of the comparison of $t_{\text {count }}$ with $t_{\text {table }}$ is 3.147 $>1.672$ with a significance value of $0.003<0.05$. So, it can be concluded that the brand image variable has a significant positive effect partially on consumer buying interest. The results of the calculation of the $t_{\text {test }}$ of the price variable showed that the comparison value of $t_{\text {count }}$ with $t_{\text {table }}$ was $5.419>1.672$ with a significance value of $0.000<0.05$. It can be concluded that the product quality variable has a partially positive effect on consumer buying interest.

Based on the $t_{\text {test }}$, it can be concluded that the Product Quality variable that has a dominant influence on the buying interest of IM3 Ooredoo prepaid simcard consumers. These are the results of the Multiple Linear Regression Test.

$Y=\alpha+\beta_{1} X_{1}+\beta_{2} X_{2}+e$

$Y=2,422+0,421 X_{1}+0,289 X_{2}+e$

Table 3 Coefficient of Determination $\left(\mathrm{R}^{2}\right)$

\begin{tabular}{|c|c|c|c|c|}
\hline Model & $\mathrm{R}$ & R Square & $\begin{array}{l}\text { Adjusted R } \\
\text { Square }\end{array}$ & $\begin{array}{l}\text { Std. Error of the } \\
\text { Estimate }\end{array}$ \\
\hline 1 & $.0760^{\mathrm{a}}$ & .578 & .564 & 1.004 \\
\hline
\end{tabular}

Source: Processed Data researcher (2019)

From the table 3, it is known that the value of $\mathrm{R}$ Square is 0.578 or $57.8 \%$. This value indicates that $57.8 \%$ of consumer buying interest $(\mathrm{Y})$ is influenced by brand image (X1), and product quality (X2). The $\mathrm{R}_{\text {Square }}$ value is good because it is 0.5 , while the remaining $42.2 \%$ is influenced by other variables outside the study. The coefficient of determination is seen from the value of $\mathrm{R}$ Square because the independent variable is more than one.

\subsection{Brand Image Against IM3 Ooredoo Prepaid Consumer Simcard purchasing decisions}

The results of the above study show that brand image partially influences the purchasing decision of IM3 Ooredoo prepaid simcard consumers. This is evidenced by conducting a $t_{\text {test }}$ in which the results of the calculation of the value of $t_{\text {count }}$ for the brand image variable $3.147>1.672$ with a significance value of $0.003<0.05$ means that the brand image variable (X1) significantly influences the consumer's buying decision. Brand image is one of the identities or logos of a company that serves to facilitate consumers in the selection or purchase of certain products. In addition, a good brand image will greatly affect buying interest. So that consumers' perceptions will put high trust in the product. This research is in accordance with previous research the effect of product quality, brand image, and promotion of interest in buying acer notebooks in Yogyakarta. In this research the brand image variable significantly influences buying interest [14].

\subsection{Product Quality on IM3 Ooredoo Prepaid Consumer Simcard purchasing decisions}

The results of this study indicate Product Quality has a significant influence on consumer buying interest on IM3 Ooredoo prepaid simcards. This is evidenced from the results of the $t_{\text {test }}$ where the results of the calculation of the $\mathrm{t}_{\text {count }}$ for the product quality variable $5.419>1.672$ with a significance value of $0.000<0.05$ means that the quality product (X2) significantly influence consumer purchasing decisions. A product is an item that is offered to consumers in accordance with their needs and desires. One of the main values that customers expect is a high-quality product, with the characteristics possessed by these products can increase consumer interest in purchasing decisions. This research is in accordance with previous research from the Influence of brand image, product quality, and prices against interest in buying children's clothing. In this research product quality variables significantly influence buying interest [6]

\subsection{Brand Image and Product Quality on IM3 Ooredoo Prepaid Consumer Simcard Purchase Decisions}

Based on the results of the simultaneous test shows the Fcalculated value of 39.086 with an expected significance of 0.000 . When compared with the expected significance level of $5 \%$, the significance of the F-count is smaller than the expected significance level $(0 \%<5 \%)$. The perception of brand image and product quality simultaneously has a positive and significant effect on consumer purchasing decisions. One form of consumer behavior is consumer interest or desire for goods or services. Buying interest is formed from the attitude of consumers towards a product with a certain brand. Consumers who have an interest in buying a product show a sense of pleasure towards the product that is followed so that they have plans to make a purchase. This study is in accordance with previous research the effect of brand image factors and product quality on purchasing interests of gita clothing modiste customers in Yogyakarta [19]. In this research the brand image and product quality variables significantly influence buying interest. 
Word Of Mouth Terhadap Minat Beli (Studi pada Mahasiswa Fakultas Ekonomi UNY Pengguna iPhone). Jurnal Manajemen Bisnis Indonesia, 5(3): 246-256

Based on the results of research testing two conclusions can be drawn. First, the effect of brand image perception and product quality has simultaneous/joint influence on IM3 Ooredoo's prepaid consumer simcard purchasing decisions. Second, the two independent variables that have a significant dominant effect on IM3Ooredoo prepaid consumer simcard purchasing decisions are product quality variables.

From the results of the research conducted by researchers provide input. To increase buying interest in consumers, it is recommended that Indosat Ooredoo company further improve the quality of its products, especially in $4 \mathrm{G}$ network problems, plus sometimes it is still unstable. In order, IM3 Ooredoo prepaid simcard consumers will trust even more with its quality in accordance with the brand (brand) that has long been known by the public. Indosat Ooredoo provides bonuses or choices for more and cheaper internet packages so that consumers of IM3 Ooredoo prepaid simcards are more comfortable using their products. Indosat Ooredoo pays more attention to poor internet connection speeds so that IM3 Ooredoo prepaid simcard consumers can get what they want. Indosat Ooredoo is always consistent with the product program that has been created so that IM3 Ooredoo prepaid simcard consumers feel happy and satisfied with the company's services.

\section{ACKNOWLEDGMENT}

The author would like to thank the Chancellor of the University of Muhammadiyah Surabaya for funding support for this research.

Acknowledgments were also conveyed to LP3I of the Muhammadiyah University of Surabaya and all of the faculty and economics faculty colleagues in completing this research and paper.

\section{REFERENCES}

[1] J. Clerk Maxwell, A Treatise on Electricity and Magnetism, 3rd ed., vol. 2. Oxford: Clarendon, 1892, pp.68-73.

[2] https://www.indosatooredoo.com/laporantahunan2013-2017(Accessed on: 31/12/2018)

[3] http://www.topbrand-award.com/2013-2017

(Accessed on: 25/12/2018)

[4] Rofiq and M. Hufrom. 2018. Pengaruh Kualitas Produk, Harga Dan Lokasi Terhadap Keputusan Pembelian Di Powernoise Store (Studi Kasus Pada Konsumen Powernoise Store Malang). Jurnal Riset Manajemen, 7(2):152-167

[5] I.J.K.G. Prabowo and Nurhadi. 2016. Pengaruh Citra Merek, Kualitas Produk, Persepsi Harga Dan
[6] N. Wijayasari and Mahfudz. 2018. Pengaruh Brand Image, Kualitas, Persepsi Harga Dan Variasi Produk Terhadap Minat Beli Konsumen Sarung Gajah Duduk Di Kabupaten Pekalongan. Diponegoro Journal Of Management, 7(2):1-9

[7] A.F. Septanto, A.T. Haryono and C. Harini. 2018. Pengaruh Kualitas Produk, Citra Merk, Persepsi Harga Terhadap Emotional Response Dengan Minat Beli Sebagai Variabel Intervening (Studi Komparatif Terhadap Produk Adidas Dan Nike). Journal of Management, 4(4): 140-158

[8] Mochklas, M., Panggayudi, D.S., \& Soenarto. 2019. The Work Culture of South Korean Companies In Indonesia. Humanities \& Social Sciences Reviews, 7(4):603-60

[9] N. Fatmawati and E. Soliha. 2017. Kualitas Produk, Citra Merek Dan Persepsi Harga Terhadap Proses Keputusan Pembelian Konsumen Sepeda Motor Matic "Honda". Jurnal Manajemen Teori dan Terapan, 10(1):1-10

[10] Firmansyah, M. A., \& Mahardhika, B. W. (2015). Pengaruh Strategi Marketing Mix (Produk, Harga, Promosi Dan Distribusi) Terhadap Keputusan Pembelian Konsumen Batik Di Surabaya. Jurnal Balance, 12 (02)

[11] P. Kotler and G. Armstrong. (2012). Principles of Marketing. Prentice-Hall, Inc, New Jersey.

[12] P. Kotler. (2008). Manajemen Pemasaran. Edisi 12 Jilid 2. Jakarta: Indeks

[13] Fatihudin, D., Jusni \& M. Mochklas, 2018, How Measuring Financial Performance, International Journal of Civil Engineering and Technology (IJCIET), 9(6):553-557

[14] Limakrisna, Nandan \& Wilhelmus Hary Susilo. Manajemen Pemasaran Teori dan Aplikasi dalam Bisnis. Jakarta: Mitra Wacana Media 2012

[15] Himawan Hira A. (2016). Pengaruh Kualitas Produk, Citra Merek, Dan Promosi Terhadap Minat Beli Notebook Acer. Skripsi. Universitas Negeri Yogyakarta.

[16] Hariani. (2013). Analisis pengaruh bauran pemasaran terhadap minat beli konsumen menggunakan gas LPG Di Desa Rambah Utama. 
[19] Aprianitasari. 2015. Pengaruh Persepsi Nilai, Persepsi Harga Dan Citra Merek Terhadap Minat Pembelian Produk Merek Toko (Studi kasus pada konsumen Supermarket Super Indo di Yogyakarta). Skripsi. Jurusan Manajemen Fakultas Ekonomi Universitas Negeri Yogyakarta.
[18] Abdullah, Thamrin \& Francis, Tantri. (2012). Manajemen Pemasaran. Jakarta: Rajawali Pers
[17] Adi, Arief Satria. (2017). Pengaruh Harga.

Promosi, dan Kualitas Produk Terhadap Minat Beli

Konsumen Pada Perusahaan A-36. Skripsi. Universitas

Ciputra Surabaya. 